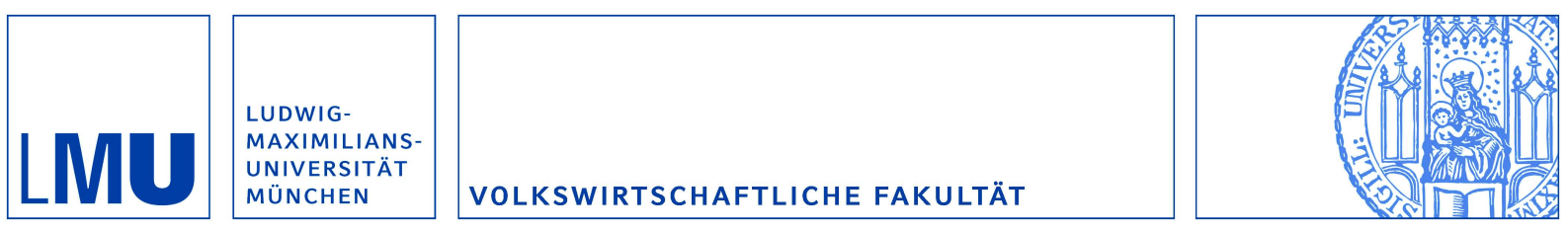

Fidrmuc, Jarko:

Money Demand and Disinflation in Selected CEECs during the Accession to the EU

Munich Discussion Paper No. 2006-31

Department of Economics

University of Munich

Volkswirtschaftliche Fakultät

Ludwig-Maximilians-Universität München

Online at https://doi.org/10.5282/ubm/epub. 1232 


\title{
Money Demand and Disinflation in Selected CEECs during the Accession to the EU*
}

September 2006

Jarko Fidrmuc

University of Munich, Department of Economics; CESifo; and

Comenius University, Department of Applied Mathematics and Statistics, Bratislava

Geschwister-Scholl-Platz 1, 80539 Munich, Germany

e-mail: jarko.fidrmuc@1rz.uni-muenchen.de and jarko.fidrmuc@fmph.uniba.sk.

\begin{abstract}
A panel data set for six countries (Czech Republic, Hungary, Poland, Romania, Slovakia, and Slovenia) is used to estimate money demand with panel cointegration methods over the recent disinflation period. The basic money demand model is able to convincingly explain the long-run dynamics of M2 in the selected countries. However, money demand is found to have been significantly determined by the euro area interest rates and the exchange rate against the euro, which indicates possible instability of money demand functions in the CEECs. Therefore, direct inflation targeting is an appropriate monetary regime before the eventual adoption of the euro.
\end{abstract}

Keywords: Money demand, panel unit root tests, panel cointegration, direct inflation targeting, CEECs.

JEL Classification: E41, E58, C23.

\footnotetext{
* I benefited from comments by Abdur Chowdhury, Ronald MacDonald, Lucjan Orlowski, Jesús CrespoCuaresma, Iikka Korhonen, Robert Kunst, and Doris Ritzberger-Grünwald.
} 


\section{Introduction}

Inflation in Central and Eastern European countries (CEECs) has figured prominently in current research (see, for example Fischer et al., 2002). More recently, disinflation received increased attention as a part of the fulfilment of Maastricht criteria. As the CEECs have joined the European Union $(E U)^{1}$ and as five of them (Slovenia and Slovakia, as well as Estonia, Latvia and Lithuania, which are not analyzed here) have already entered the Exchange Rate Mechanism II (ERM II), the environment conditions for monetary policy in these countries are becoming increasingly important. From this perspective, the determinants and the stability of money demand are crucial. Stable money demand and a transmission mechanism similar to that in the euro area are likely to create good preconditions for the eventual introduction of euro by new member states (see Elbourne and de Haan, 2006).

Calvo and Kumar (1994) and Budina et al. (1995) provide an early comparative study on determinants of money demand in selected CEECs, while other authors offer insights on individual countries: Buch (2001) estimates money demand for Hungary and Poland, Komárek and Melecký (2003) for the Czech Republic, Ross (1998) for Slovenia, Slavova (2003) for Bulgaria, and Mehrotra (2006) for China. Similarly, Crespo-Cuaresma et al. (2005) show that the monetary model of exchange rates is able to explain the long-run dynamics of nominal exchange rates vis-à-vis the euro in CEECs. However, the analyses of money demand are available only for the highinflation episodes during the early years of the economic transition, but not for the current period of successful disinflation during and after accession to the EU (see Figure 1). This paper aims to fill this surprising gap in the current literature by estimating money demand functions for a panel of relatively homogenous CEECs (Czech Republic, Hungary, Poland, Romania, Slovakia, and Slovenia).

Besides this, our paper is also relevant for countries using direct inflation targeting as a framework for their monetary regime (see Svensson, 2000, and Orlowski, 2001 and 2005), even more so as several CEECs have recently adopted direct inflation targeting as a tool for disinflating to EU rates. Nelson (2003) argues that the monetary

\footnotetext{
${ }^{1}$ We concentrate in this contribution on the Czech Republic, Hungary, Poland, Slovakia, and Slovenia, which joined the EU in May 2004, and on Romania, which is expected to follow in 2007.
} 
aggregates provide important information for central banks in inflation targeting countries. By contrast, Dotsey and Hornstein (2003) see unstable money demand as a possible source of shocks. Fraga et al. (2003) also point out that unstable money demand may trigger unexpected monetary shocks, posing new challenges for direct inflation targeting in emerging economies. ${ }^{2}$

The paper is structured as follows. The next section describes the disinflation process and the panel data set for six CEECs (Czech Republic, Hungary, Poland, Romania, Slovakia, and Slovenia). Section 4 contains a set of unit root tests, while section 5 presents several estimates of money demand. The final section offers concluding remarks.

\section{Disinflation in Central and Eastern Europe}

Although we have access to monthly data from 1994 to the end of 2005 (see Figure 1), our analyses concentrate on the period between September 1994 and June 2003. This allows us to use panel cointegration methods for estimating the money demand function in a balanced sample. At the same time, this avoids any structural break related to the accession to the European Union in May 2004 (given also possible anticipatory effects before the Eastern enlargement of the EU).

Six Central and Eastern European countries are included in our data sample (Czech Republic, Hungary, Poland, Romania, Slovakia, and Slovenia). During the sample period, several countries in our sample have moved from monetary regimes characterized by adjustable pegged exchange rates to direct inflation targeting accompanied by managed or free floating exchange rates, and towards ERM II participation (in Slovenia and Slovakia) after the EU accession (omitted from the later analysis). These changes could have some implications for monetary policy and money demand functions, although the CEECs had significant de-facto flexibility of exchange

\footnotetext{
${ }^{2}$ Given the objective of these countries to fulfil the inflation Maastricht criterion (that is, to reduce the inflation differential to the three best performing EU countries below 1.5 percentage points), the Czech Republic, Hungary, Poland, Romania and Slovakia (in a combination with the ERM II participation) have recently introduced official inflation targets (see Jonas and Mishkin, 2003).
} 
rates during the whole analyzed period (see Reinhart and Rogoff, 2004). ${ }^{3}$ The degree of monetization of the economy and the degree of development of the banking sector differ also across countries (see Hainz, 2004). Therefore, the countries in our sample do not represent a fully homogeneous group. Sensitivity analyses were performed to see if the time series on real money demand behaved differently after the abolishment of exchange rate pegs. ${ }^{4}$ Similarly to stability tests by Buch (2001) for Hungary and Poland, we found no indications for structural breaks in our time series. However, in the Czech Republic and Slovakia, the variance of several nominal variables was higher around the periods of policy changes (see Figure 1).

The variables in our data set comprise the real broad money stock (M2), consumer prices, real industrial production, and interest rates (deposit rates) in the CEECs. All variables except interest rates were seasonally adjusted and indexed to the base year of 1995 as $100 \%$, and they were all converted into natural logarithms. Wherever possible, time series data are taken from the International Financial Statistics of the IMF. The remaining variables are taken from national sources and publications of the Vienna Institute for Comparative Economics (WIIW).

The monetary variables are strongly influenced by the achieved degree of disinflation (see Figure 1). In the mid-1990s, all CEECs reported two-digit annual inflation rates, with the exception of Romania, whose annual inflation rate exceeded $100 \%$ in 1994, 1995, and 1997. By the time of the EU accession, the Czech Republic and Poland had stabilized their inflation rates at the historically lowest figures below $2 \%$. The only country to report double-digit inflation rates (15.3\% in 2003) at the end of our sample period was Romania. However, there was a revival of inflation in some CEECs immediately before and after the accession to the EU, while Romania continued its disinflation process to one-digit annual inflation rates at the end of 2005.

\footnotetext{
${ }^{3}$ The changes in the monetary regime took place in the Czech Republic in 1997, in Slovakia in 1998, in Poland in 2000, and finally in Hungary in 2001.

${ }^{4}$ Estimations with the longer, unbalanced sample were used in order to check the robustness of the parameter estimates to the inclusion of earlier transition periods (available upon request from author). In general, the parameters remain in the range of those presented for the balanced sample.
} 

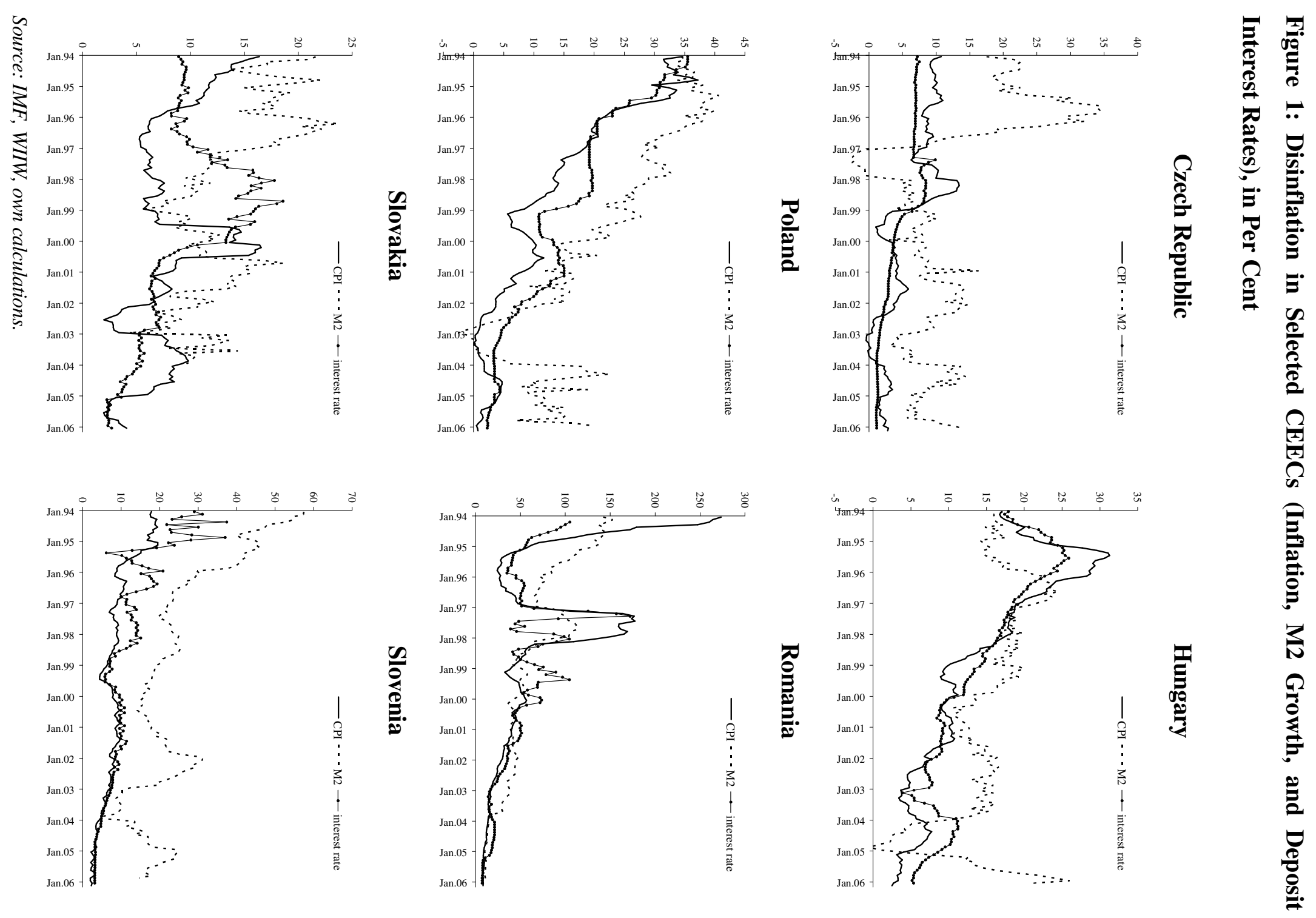


\section{Panel Unit Root Tests}

Given the catching-up of the CEECs, we would expect the real money and industrial production series to display a clear trend pattern. Standard unit root tests for single time series (not reported here) confirm that the majority of individual time series are I(1) processes. ${ }^{5}$ Adding a cross-section dimension to unit root tests can potentially improve the quality of these tests significantly by increasing their power. ${ }^{6}$

Levin and Lin (1992) have significantly influenced the discussion of panel unit root tests for a panel of $N$ individuals, where each individual contains $T$ time series observations. They proposed a panel version of the Dickey-Fuller test ( $D F$ test) with fixed effects, individual deterministic trends and serially correlated errors. Levin et al. (2002) proposed a new more general test ( $L L C$ test), which is appropriate also for panels of moderate size ( $N$ between 10 and 250 individuals and $T$ between 25 and 250 periods). These dimensions are close to our panel.

The generality of the Levin-Lin type tests has made them a widely accepted panel unit root test. However, Levin and Lin have an important homogeneity restriction of the autoregressive parameter in their tests, as the null hypothesis assumes that $\rho_{i}=\rho=0$ against the alternative $\rho_{i}<0$ for all cross-section units $i$. As far as this result also reflects the possible speed of convergence, the Levin and Lin type tests are likely to reject the panel unit root.

Therefore, Im et al. (2003) address this homogeneity issue, proposing a heterogeneous panel unit root test (IPS test) based on individual ADF tests. They propose average $A D F$ statistics. By construction of the heterogeneous panel unit root test, the rejection of the null of panel unit root does not necessarily imply that the unit root is rejected for all cross-sectional units, but only for a positive share of the sample. Finally, Hadri (2000) presents an extension of the test of Kwiatkowski et al. (1992) to a panel with individual and time effects and deterministic trends (PKPSS test), which has as its null the stationarity of the series.

\footnotetext{
5 The results of the Augmented Dickey Fuller test ( $A D F$ test) and of the test according to Kwiatkowski et al., 1992) for all variables are available from the authors on request. For the interest rate in the euro area, which is used in the subsequent analysis, the ADF test with two lags is -1.236 for the levels and -4.889 for the first differences (critical values are -2.889 at $5 \%$ and -3.493 at the $1 \%$ significance level).

${ }^{6}$ Banarjee (1999) provides detailed surveys of panel unit root tests.
} 
In general, the panel unit root tests confirm that the variables contain a unit root (see Table 1). The panel version of the KPSS does not reject the null hypothesis of stationarity for any of the variables. A similar result pertains for the IPS test although this test (with time dummies) rejects the null of unit root for interest rates. Individual country results show that this ambiguous outcome is influenced mainly by the Romanian interest rates. The IPS test confirms that all differenced variables are stationary. However, the KPSS test rejects the null of stationarity again for first differences of real money and industrial production. Despite some ambiguity of the results, we conclude that the variables are $\mathrm{I}(1)$.

Table 1: Panel Unit Root Tests, 1994:9-2003:6

A. Levels

\begin{tabular}{|c|c|c|c|c|}
\hline & $\begin{array}{c}\text { Real Money } \\
\text { (M2) }\end{array}$ & $\begin{array}{c}\text { Industrial } \\
\text { Production }\end{array}$ & $\begin{array}{c}\text { Domestic } \\
\text { Interest Rate }\end{array}$ & $\begin{array}{c}\text { Exchange } \\
\text { Rate }\end{array}$ \\
\hline$I P S$-test & -0.152 & 2.122 & 0.162 & -0.778 \\
\hline$I P S^{T D}$-test & -0.697 & -0.584 & $-3.375^{* * *}$ & -0.200 \\
\hline$L L C$-test & $-3.227^{* * *}$ & -0.324 & -0.324 & $-2.529^{* * *}$ \\
\hline$L L C^{T D}$-test & $-2.141^{* *}$ & $-1.348^{*}$ & $-1.811^{* *}$ & $-2.900^{* * *}$ \\
\hline$P K P S S$-test & $9.790^{* * *}$ & $12.782^{* * *}$ & $10.457^{* * *}$ & $19.468^{* * *}$ \\
\hline$P K P S S^{T D}$-test & $10.992^{* * *}$ & $13.575^{* * *}$ & $10.563^{* * *}$ & $15.782^{* * * *}$ \\
\hline
\end{tabular}

B. First Differences

\begin{tabular}{lrrrr}
\hline & $\begin{array}{c}\text { Real Money } \\
(\mathbf{M 2})\end{array}$ & $\begin{array}{c}\text { Industrial } \\
\text { Production }\end{array}$ & $\begin{array}{c}\text { Interest } \\
\text { Rate }\end{array}$ & \multicolumn{1}{c}{$\begin{array}{c}\text { Exchange } \\
\text { Rate }\end{array}$} \\
\hline$I P S$-test & $-5.357^{* * * *}$ & $-10.388^{* * *}$ & $-8.664^{* * * *}$ & $-8.398^{* * * *}$ \\
$I P S^{T D}$-test & $-6.632^{* * *}$ & $-11.159^{* * *}$ & $-13.771^{* * *}$ & $-8.528^{* * *}$ \\
$L L C$-test & 0.651 & 7.396 & 0.421 & $-3.329^{* * * *}$ \\
LLC $^{T D}$-test & -0.435 & 6.227 & $-6.885^{* * *}$ & $-3.170^{* * *}$ \\
$P K P S S$-test & $8.079^{* * *}$ & $1.609^{*}$ & -1.589 & 0.167 \\
$P K P S S^{T D}$-test & $8.829^{* * *}$ & $2.308^{* *}$ & -1.673 & 0.306
\end{tabular}

Notes: $T D$ denotes the inclusion of time dummies. IPS test with 2 lags (based on the maximum number of lags implied by SIC for the individual tests); PKPSS test with lag truncation of 5 lags. The panel includes the Czech Republic, Hungary, Poland, Romania, Slovakia and Slovenia. All variables except interest rates are in logs. Variables are seasonally adjusted if necessary (money supply, industrial production). $* / * * * * * *$ denote significance at the $10 \% / 5 \% / 1 \%$ level. 


\section{Estimation of the Long-Run Money Demand}

The money demand function in the CEECs is analyzed using a general two-country portfolio balance model described in Leventakis (1993). The assets held by residents in the home country and the foreign country include domestic money, foreign money, domestic bonds, and foreign bonds. The home country residents' demand for domestic money is assumed to depend on a scale variable and the rates of return to the four assets. The nominal rate of return on domestic money is zero, while the expected rate of return on foreign money is the expected depreciation of the domestic currency. The domestic interest rate represents the nominal rate of return on domestic bonds, while the foreign interest rate measures the nominal rate of return on foreign bonds. Therefore, depreciation of the domestic currency lowers the demand for domestic money by leading to its substitution with foreign money and foreign bonds.

Following these arguments, the open-economy version of money demand can be summarized as follows (see Chowdhury, 1995),

$$
m_{i t}-p_{i t}=\mu_{i}+\alpha_{1} y_{i t}+\alpha_{2} R_{i t}+\varepsilon_{i t},
$$

where $m, p, y$ and $R$ are defined as money, prices, output and domestic interest rates, respectively. This specification assumes that the nominal money demand is homogenous in prices. Sensitivity analysis confirms this assumption. Various specifications of the model include fixed effects (denoted by $\mu$ ) or a common intercept. Equation (1) represents the desired or long-run real money demand function under the assumption of a long-run unitary elasticity of the nominal cash balances with respect to the price level. We tested the assumption of price homogeneity (see also Buch, 2001), which is confirmed for our sample.

Several authors have included wealth-related additional variables as further determinants of money demand (see recent surveys by Knell and Stix, 2005 and 2006). An increase in wealth is expected to lead to an increase in the demand for financial assets, including money. As monthly data are used for estimation, we can not include any variable representing this effect because possible proxies tend to be strongly correlated with the scale variable. Nevertheless, fixed effects in panel estimations are likely to cover a substantial part of time-invariant cross-section differences in wealth across countries. The same is also true for expected differences in financial development (e.g. the size of the banking sector, the use of credit cards, etc.). 
Finally, the exchange rate and the euro area interest rates (see Leventakis, 1993) are included in the open-economy formulation of the money demand,

$$
m_{i t}-p_{i t}=\mu_{i}+\alpha_{1} y_{i t}+\alpha_{2} R_{i t}+\alpha_{3} R_{t}^{*}+\alpha_{4} e_{i t}+\varepsilon_{i t},
$$

where, in addition to the previous variables, $R^{*}$ stands for the euro area interest rates and $e$ is the nominal exchange rate (in logs) defined on the basis of nominal exchange rate (expressed as units of domestic currency per 1 euro). Correspondingly, depreciation or devaluation is displayed as an upward movement of $e$. We expect that external weakness of the currency will lower domestic demand, for example through a higher demand for foreign currency.

The previous section showed that money demand and the right-hand side variables in the money demand equations (2) and (3) are I(1). Furthermore, the standard money demand models predict that these variables should be cointegrated. Therefore, we consider several approaches to estimating the long-run (cointegrating) relationship between the variables. Kao and Chiang (2000) show that the panel OLS estimator is asymptotically normal, but it is still asymptotically biased. Although they propose a correction for this bias, it has been found that this correction does not tend to perform well at reducing the bias in small samples. Therefore, alternative methods of panel cointegration estimation have been proposed.

Pedroni (1996 and 2001) proposes the fully modified OLS estimator (FMOLS), while Kao and Chiang (2000) recommend the dynamic OLS (DOLS). Both approaches take into account the potential endogeneity of involved variables. Pedroni's FMOLS corrects for the endogeneity and serial correlation to the OLS estimator nonparametrically, while the DOLS uses the future and past values of the differenced explanatory variables as additional regressors. Kao and Chiang show that both estimators have the same (normal) limiting properties, although they are shown to perform differently in empirical analyses. The FMOLS does not improve the properties of the simple OLS estimator in finite samples. Correspondingly, DOLS can be considered to be more promising for the estimation of panel cointegration. The results for the individual estimators of money demand are listed in Table 2, with and without fixed effects. Furthermore, we present a DOLS specification accounting for the contemporaneous correlation in the errors across countries by a seemingly unrelated regression (SUR). 
Table 2: Panel Cointegration Estimation of Money Demand (Closed Economy Formulation), 1994:9-2003:6

\begin{tabular}{lrrrrr}
\hline & OLS & FE & FMOLS & DOLS & DOLS-SUR \\
\hline Industrial production & 0.470 & 0.726 & 1.059 & 0.644 & 0.664 \\
& $(9.457)$ & $(18.266)$ & $(0.932)$ & $(15.086)$ & $(52.480)$ \\
Interest rates & -0.002 & -0.003 & -0.009 & -0.006 & -0.005 \\
& $(-5.038)$ & $(-6.079)$ & $(-15.147)$ & $(-8.290)$ & $(-12.235)$ \\
No. of observations per country & 106 & 106 & 106 & 106 & 106 \\
Total no. of observations & 636 & 636 & 636 & 636 & 636 \\
Fixed effects & no & yes & yes & yes & Yes \\
\hline
\end{tabular}

Notes: The panel includes the Czech Republic, Hungary, Poland, Romania, Slovakia and Slovenia. All variables except interest rates are in logs. Variables are seasonally adjusted if necessary (money supply and industrial production). $t$-statistics are in parentheses.

Table 3: Residual Panel Cointegration Tests (Closed Economy Formulation), 1994:9-2003:6

\begin{tabular}{lcrrrr}
\hline & OLS & FE & FMOLS & DOLS & DOLS-SUR \\
\hline$D F_{\rho}$ test & 1.919 & $-1.507^{*}$ & $-3.988^{* * *}$ & $-2.389^{* * * *}$ & $-1.899^{* *}$ \\
$D F_{t}$ test & 2.814 & $-2.109^{* *}$ & $-5.593^{* * *}$ & $-3.367^{* * * *}$ & $-2.670^{* * *}$ \\
$D F_{\rho}{ }^{*}$ test & 0.036 & $-6.007^{* * *}$ & $-10.306^{* * *}$ & $-7.508^{* * *}$ & $-6.684^{* * *}$ \\
$D F_{t}^{*}$ test & 0.453 & $-2.159^{* *}$ & $-4.126^{* * *}$ & $-2.879^{* * *}$ & $-2.472^{* * *}$ \\
Panel $A D F$ test & 0.486 & $-2.029^{* *}$ & $-2.485^{* * *}$ & $-2.199^{* *}$ & $-2.021^{* *}$ \\
\hline
\end{tabular}

Notes: See Table 2. */**/*** denote significance at the $10 \% / 5 \% / 1 \%$ level.

Already the estimation of a standard money demand function for a closed economy yields comparably good results. All variables have correct signs and nearly all of them are highly significant (see Table 2). The coefficient of industrial production is significantly different from unity in all specifications, with the exception of FMOLS, where the coefficient is insignificant. Thus, the output elasticity of money demand is lower than values typically found for the euro area, although Stracca (2003) finds output elasticities of M3 close to our estimates. Furthermore, we use industrial production as a proxy for the scale variable, which grew much faster than GDP (used in comparable studies for other regions). We have also to take into account the formulation of our econometric specification. In particular, Knell and Stix (2005 and 2006) show that time 
series with higher frequencies and the inclusion of wealth variables (e.g. by fixed effects here) are likely to lead to relatively lower estimates of output elasticities. In a panel of OECD countries, Mark and Sul (2003) find output elasticities relatively close to our estimates (0.860). In turn, the effect of the interest rate is estimated at similar values across the specifications. Furthermore, the long-run semi-elasticity with respect to the domestic interest rate is very close to the values reported by Leventakis (1993) and Chowdhury (1995).

The inclusion of the exchange rate and of euro area interest rates confirms the robustness of the basic model of money demand in CEECs (see Table 4). The coefficient estimated for the domestic interest rates remains nearly unchanged, but the size of coefficient estimates for the industrial production is lower in the open economy specification of money demand than in the previous models. All coefficient estimates of the industrial production are now below one. The DOLS estimate of the output elasticity, for example, drops from approximately two-thirds in the closed economy specification to approximately one-third in the open economy formulation of the money demand.

The euro area interest rates have significantly shaped money demand in the CEECs, which indicates that the capital mobility effect plays an important role in the CEECs. Somewhat surprisingly, the coefficient estimated for the interest rate in the euro area is much larger than the coefficient of domestic interest rates. The semi-elasticities of money demand with respect to the foreign interest rates are generally reported to be slightly higher than those for the domestic interest rates (see Leventakis, 1993). Furthermore, our results may reflect the different definition of the euro area and domestic interest rates, which are treasury rates and deposit rates, respectively. For the shorter period with both types of interest rates available for the euro area, we can see that treasury rates are usually lower than the deposit rates. As expected, the exchange rate is revealed to have negative effects on money demand, but the estimated elasticity is low. This indicates that currency substitution does not play an important role in the CEECs. 
Table 4: Panel Cointegration Estimation of Money Demand (Open Economy Formulation), 1994:9-2003:6

\begin{tabular}{lrrrrr}
\hline & OLS & FE & FMOLS & DOLS & DOLS-SUR \\
\hline Industrial production & 0.227 & 0.433 & 0.539 & 0.312 & 0.393 \\
& $(4.426)$ & $(9.869)$ & $(7.841)$ & $(6.167)$ & $(17.856)$ \\
Domestic interest rates & -0.002 & -0.003 & -0.009 & -0.007 & -0.005 \\
& $(-4.460)$ & $(-6.400)$ & $(-21.407)$ & $(-9.690)$ & $(-10.514)$ \\
Foreign interest rate & -0.062 & -0.050 & -0.032 & -0.056 & -0.048 \\
& $(-10.013)$ & $(-11.587)$ & $(-8.767)$ & $(-11.386)$ & $(-20.224)$ \\
Exchange rate & -0.032 & -0.040 & -0.025 & -0.071 & -0.055 \\
& $(-2.023)$ & $(-2.626)$ & $(-27.789)$ & $(-4.106)$ & $(-5.783)$ \\
No. of observations per country & 106 & 106 & 106 & 106 & 106 \\
Total no. of observations & 636 & 636 & 636 & 636 & 636 \\
Fixed effects & no & yes & yes & yes & yes \\
\hline
\end{tabular}

Notes: See Table 2. $t$-statistics are in parentheses.

Table 5: Residual Panel Cointegration Tests (Open Economy Formulation), 1994:9-2003:6

\begin{tabular}{lcrcrc}
\hline & OLS & FE & FMOLS & DOLS & DOLS-SUR \\
\hline$D F_{\rho}$ test & 2.119 & -0.938 & $-4.521^{* * *}$ & $-3.293^{* * *}$ & $-1.794^{* *}$ \\
$D F_{t}$ test & 3.086 & $-1.499^{*}$ & $-6.679^{* * *}$ & $-4.960^{* * *}$ & $-2.774^{* * *}$ \\
$D F_{\rho}{ }^{*}$ test & 0.385 & $-5.006^{* * *}$ & $-11.083^{* * *}$ & $-8.979^{* * *}$ & $-6.488^{* * *}$ \\
$D F_{t}{ }^{*}$ test & 0.587 & $-1.828^{* *}$ & $-4.892^{* * *}$ & $-3.864^{* * *}$ & $-2.533^{* * *}$ \\
Panel $A D F$ test & 0.595 & $-1.711^{* *}$ & $-3.155^{* * *}$ & $-2.737^{* * *}$ & $-1.989^{* *}$ \\
\hline
\end{tabular}

Notes: See Table 2. */**/*** denote significance at the $10 \% / 5 \% / 1 \%$ level.

Finally, we test whether the estimated relationships truly represent cointegrating vectors in Tables 3 and 5. Following the Engle and Granger's approach, Kao (1999) proposed several tests based on a homogenous panel version of the residual DickeyFuller test. Kao's panel cointegration tests are based both on the autoregressive coefficient (denoted by $D F_{\rho}$ ) and on the corresponding $t$-statistic $\left(D F_{t}\right)$. Furthermore, they consider the endogeneity relationship between the regressors and residuals, which is adjusted by the long-run conditional variance of the residuals. The corresponding test statistics for the autoregressive coefficients and the $t$-statistics are denoted by $D F_{\rho}{ }^{*}$ and 
$D F_{t}{ }^{*}$, respectively. Finally, Kao proposes a panel version of the residual $A D F$ test, which is again corrected for a possible endogeneity relationship between the regressors and the residuals.

All tests reveal nearly the same picture (see Table 3 and Table 5). On the one hand, the panel cointegration tests for FMOLS, DOLS and to a lesser extent for DOLS with SUR errors confirm the stationarity of the residuals. The methods suggested in the literature seem to perform similarly in our data sample. At the same time, the majority of the tests rejects cointegrating relationship for the OLS specification.

\section{Conclusions}

The analyses of money demand in the CEECs have gained an increased importance recently as the new EU Member States have started the preparation for a full participation in the monetary union. This reflects that the monetary policy of the European Central Bank puts a strong emphasis on the development of monetary aggregates (in particular M3), which constitute the so-called 'monetary pillar' of its monetary strategy. Correspondingly, there are a large number of studies analyzing money demand for euro area countries (see Stracca, 2003, Brand and Cassola, 2004). In contrast, there are virtually no comparative studies for the new member states in Central and Eastern Europe with regard to the recent period of disinflation and preparation for the euro adoption.

Filling this gap in the literature, the empirical estimation presented in this paper provides the following conclusions. First, we document the relatively fast and successful process of disinflation in the CEECs. Second, we show that a simple money demand model is able to explain the long-run dynamics of broad money in the CEECs. Furthermore, the euro area interest rates are found to have a significant impact on money demand in the CEECs, which confirms the importance of capital substitution in these countries. The exchange rate is also significant, but the estimated elasticity is relatively low, which implies that currency substitution is playing a less important role in these countries.

We find parameters of money demand in the new member states to be close to those in developed countries, especially with regard to domestic interest rates. This may create good preconditions in these countries for the eventual adoption of euro. However, 
our estimates of output elasticities are somewhat lower than comparable estimates for the euro area. Nevertheless, the difference may reflect the different formulation of our econometric specifications (monthly data, definition of the scale variable, and the use of the panel data models). Finally, our results imply that the euro area interest rates are already important determinants of monetary developments in the new member states and candidate countries, which may present a possible source of instability of money demand functions in the CEECs.

As a result, the policy of direct inflation targeting, which nearly all countries in the sample adopted during the period instead of direct targets for the monetary aggregates, has been an appropriate monetary regime during disinflation and may remain appropriate until the eventual adoption of the euro.

\section{References}

Banerjee, A. (1999) Panel data unit roots and cointegration: An overview, Oxford Bulletin of Economics and Statistics, 61, 607-629.

Brand, C. and Cassola, N. (2004) A money demand system for euro area M3, Applied Economics, 36, $817-838$.

Buch, C.M. (2001) Money demand in Hungary and Poland, Applied Economics, 33, 989-999.

Budina, N., Hanousek, J. and Tuma, Z. (1995) Money demand and seigniorage in transition, in Svejnar, J. (Ed.) The Czech Republic and Economic Transition in Eastern Europe, Academic Press.

Calvo, G.A. and Kumar, M.S. (1994) Money demand, bank credit, and economic performance in former socialist economies, IMF Staff Papers, 41, 314-349.

Chowdhury, A. (1995) The Demand for Money in a Small Open Economy: The Case of Switzerland. Open Economy Review, 6, 131-144.

Crespo-Cuaresma, J., Fidrmuc, J. and MacDonald, R. (2005) The Monetary Approach to Exchange Rates in the CEECs, Economics of Transition, 13, 395-416.

Dotsey, M. and Hornstein, A. (2003) Should monetary policymaker look at money?, Journal of Monetary Economics, 50, 547-579.

Elbourne, A. and de Haan, J. (2006) Financial structure and monetary policy transmission in transition countries, Journal of Comparative Economics, 34, 1-23.

Fischer, S., Ratna, S. and Végh, C.A. (2002) Modern hyper- and high inflations, Journal of Economic Literature, 40, 837-880.

Fraga, A., Goldfajn, I. and Minella, A. (2003) Inflation Targeting in Emerging Markets Economies, Working Paper No. 10019, NBER, Cambridge.

Hadri, K. (2000) Testing for stationarity in heterogenous panel data, Econometrics Journal, 3, 148-161. 
Hainz, C. (2004) Are Transition Countries Overbanked? The Effect of Institutions on Bank Market Entry, German Economic Review, 5, 233 - 252.

Im, K.S., Pesaran, M.H. and Shin, Y. (2003) Testing for unit root in heterogenous panels, Journal of Econometrics, 115, 53-74.

Jonas, J., and Mishkin, F.S. (2003) Inflation Targeting in Transition Countries: Experience and Prospects, Working Paper No. 9667, NBER, Cambridge.

Kao, C. (1999) Spurious regression and residual-based tests for cointegration in panel data, Journal of Econometrics, 90, 1-44.

Kao, C. and Chiang, M.-H. (2000) On the estimation and inference of cointegrated regression in panel data, Advances in Econometrics, 15, 179-222.

Knell, M. and Stix, H. (2005) The income elasticity of money demand: A meta analysis of empirical results, Journal of Economic Surveys, 19, 513-533.

Knell, M. and Stix, H. (2006) Three decades of money demand studies: Differences and similarities, Applied Economics, 38, 805-818.

Komárek, L. and Melecký, M. (2003) Currency substitution in a transitional economy with an application to the Czech Republic, Eastern European Economics, 41, 72-99.

Kwiatkowski, D., Phillips, P.C.B., Schmidt, P. and Shin, Y. (1992) Testing the null hypothesis of stationarity against the alternative of a unit root: how sure are we that economic time series have a unit root?, Journal of Econometrics, 54, 159-178.

Leventakis, J. A. (1993) Modelling money demand in open economies over the modern floating rate period, Applied Economics, 25, 1005-1012.

Levin, A. and Lin, C.-F. (1992) Unit Root Tests in Panel Data: Asymptotic and Finite-Sample Properties, Working Paper No. 23, University of California, Department of Economics, San Diego.

Levin, A., Lin, C.-F. and Chu, C.-S. J. (2002) Unit root tests in panel data: Asymptotic and finite-sample properties, Journal of Econometrics, 108, 1-24.

Mark, N. C. and Sul, D. (2003) Cointegration Vector Estimation by Panel DOLS and Long-Run Money Demand. Oxford Bulletin of Economics and Statistics, 65, 655-680.

Mehrotra, A. (2006) Demand for money in transition: Evidence from China's disinflation. BOFIT Discussion Paper No. 10, Bank of Finland, Institute for Economies in Transition, Helsinki.

Nelson, E. (2003) The future of monetary aggregates in monetary policy analysis, Journal of Monetary Economics, 50, 1029-1059.

Orlowski, L. (2001) From inflation targeting to the euro-peg: a model of monetary convergence for transition economies, Economic Systems, 25, 233-251.

Orlowski, L. (2005) Monetary convergence of the EU accession countries to the eurozone: A theoretical framework and policy implications, Journal of Banking and Finance, 29, 203-225.

Pedroni, P. (1996) Fully Modified OLS for Heterogenous Cointegrated Panels and the Case of Purchasing Power Parity, Working Paper No. 96-020, Indiana University.

Pedroni, P. (2001) Purchasing power parity tests in cointegrated panels, Review of Economics and Statistics, 83, 727-731. 
Reinhart, C.M. and Rogoff, K.S. (2004) The Modern History of Exchange Rate Arrangements: A Reinterpretation, Quarterly Journal of Economics, 119, 1-48.

Ross, K. (1998) Post Stabilization Dynamics in Slovenia. Working Paper No. 98/27. International Monetary Fund, Washington, DC.

Slavova, S. (2003) Money demand during hyperinflation and stabilization: Bulgaria, 1991-2000, Applied Economics, 35, 1303-1316.

Stracca, L. (2003) The functional form of the demand for euro area M1. Manchester School, 71, 172-204.

Svensson, L.E.O. (2000) Open-economy inflation targeting. Journal of International Economics, 50, 155 183. 